\title{
Permodelan Analisis Pengaruh Tinggi Main Roll Hoop terhadap Tegangan dan Displacement Pada Mobil Formula Student Automotive Engineering
}

\author{
Hajar Isworo \\ Program Studi Teknik Mesin Universitas Lambung Mangkurat \\ hajarisworo@gmail.com
}

\begin{abstract}
ABSTRAK
Adanya ketidakstabilan dalam kendaraan ajang formula student pada saat perlombaan dengan kecepatan tinggi menuntut para desainer mobil membuat model chasis yang tahan terhadap goncangan, disamping itu bagian engineering drawing F1 student dibatasi aturan dalam menenentukan dimensi dari chasis. Tujuan diadadakannya penelitian ini adalah mengetahui pengaruh ketinggian roll hope terhadap kekuatan defleksinya. Variasi ketinggian roll hope $518 \mathrm{~mm}, 525 \mathrm{~mm}, 532 \mathrm{~mm}$. Metode yang digunakan meliputi pembuatan desain chasis, penentuan variasi ketinggian roll hope, penentuan free body diagram chasis, perhitungan menggunakan software, analisis hasil defleksi setelah pembebanan. Hasilnya defleksi terbesar 20,37 mm (tinggi roll hope $532 \mathrm{~mm}$ ), 14,94 mm (tinggi roll hope $525 \mathrm{~mm}$ ), 14,16 mm (tinggi roll hope $518 \mathrm{~mm}$ ). Kesimpulannya semakin tinggi roll hope maka defleksinya akan meningkat.
\end{abstract}

Kata Kunci : Permodelan, Chasis, Displacement, Tegangan.

\section{Latar Belakang Masalah}

Fungsi Chassis dalam kendaraan adalah menyangga beban yang berasal dari body dan beban penumpang. Kekuatan chasiss menyangga beban menjadi target utama seorang perancang. Chassis mobil yang kuat dirancang agar dapat melindungi pengemudinya dari kecelakaan, baik itu berupa benturan dari arah depan, belakang, samping (side impact), ataupun mobil terguling (rollover). Ketika mobil balap terguling, resiko cedera di bagian kepala sangat besar dihadapi oleh pebalap. Oleh karena itu, dalam dunia balap kategori single seater seperti Formula 1,
Indy Car, maupun Formula SAE menggunakan roll hoop sebagai bagian penting dari chassis untuk meningkatkan keselamatan dan keamanan pebalap jika suatu waktu terjadi kecelakaan mobil terbalik ataupun terguling.

Berdasarkan permasalahan di atas, maka penyusun mengambil judul "Pengaruh Geometri Roll Hoop terhadap Displacement pada Chassis Mobil Formula Student Automotive Engineering (FSAE)". Pengambilan judul ini dilakukan untuk mendapatkan geometri roll hoop yang mampu ngoptimalkan keselamatan pebalap terutama pada bagian kepala. Selain itu, hal ini juga sebagai usaha 
mahasiswa Teknik Mesin Universitas Lambung Mangkurat dalam merancang dan mengembangkan sebuah mobil balap tipe single seater serta memotivasi untuk ikut berkompetisi di event balap mobil F1 SAE di masa yang akan datang.

\section{2. Tinjauan Pustaka}

\subsection{Tipe chassis}

Chassis memiliki beberapa jenis yaitu ladder frame, tubular space frame, aluminium space frame, backbone chassis, dan monocoque .

\subsubsection{Ladder Frame}

Ladder frame adalah jenis chassis yang memiliki konstruksi dua batangan yang menyokong kendaraan dan mampu menahan kuat beban dan umumnya berdasarkan desain angkut. Bentuk body ini merupakan salah satu contoh yang bagus dari tipe chassis. Dinamakan demikian karena kemiripannya dengan tangga, ladder frame adalah jenis chassis yang paling sederhana dan tertua dari semua desain. Konstruksi ladder frame terdiri hanya dari dua rel simetris, atau balok, dan cross members yang menghubungkan frame.

Ladder frame merupakan chassis paling awal yang digunakan sekitar tahun 1960-an, namun sampai sekarang masih banyak kendaraan yang menggunakan chassis jenis ini terutama kendaraan jenis Sport Utility
Vehicle (SUV). Bahan material yang paling umum untuk jenis ladder frame ini adalah material dengan bahan baja ringan.

Dua batang memanjang menjadi bagian utama untuk menahan beban longitudinal akibat percepatan dan pengereman. Kemudian batang yang melintang hanya menahan agar chassis tetap dalam keadaan rigid atau kaku.

Dalam hal lain chassis ladder frame ini ada juga penambahan komponen untuk lebih menguatkan chassis yaitu dengan cara penambahan diagonal cross - bracing berupa paling membentuk huruf $\mathrm{X}$. Hal ini dimungkinkan untuk merancang kerangka untuk membawa beban torsi di mana tidak ada unsur frame dikenakan saat torsi. Diagonal cross - bracing terbuat dari dua balok lurus dan hanya akan memiliki beban lentur diterapkan pada balok.

Jenis frame ini memiliki kekakuan torsi yang baik terbagi di pusat rancangan frame ladder. Perlu diketahui bahwa beban lentur maksimum terjadi pada bagian sambungannya oleh karena itu bagian sambungan (joint) menjadi kritis. Menggabungkan sifat dari diagonal cross bracing dengan ladder frame membantu dalam memperoleh kedua sifat baik beban lentur dan torsi. Dapat dilihat pada gambar 2.1 balok silang di bagian depan dan 
belakang tidak hanya membantu pada saat terjadi torsi tetapi juga membantu dalam membawa beban lateral dari titik pemasangan suspensi.

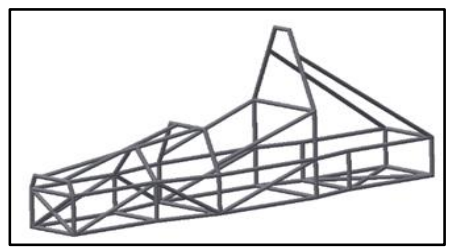

Figure 2.1 Tubular Space Frame Chassis Source: Autodesk Inventor Pro 2016

\subsubsection{Tubular Space Frame}

Tubular space frame adalah salah satu jenis chassis terbaik yang dikenal dengan kekuatan luluh yang bagus, kekakuan torsional, ketahanan beban berat, dan ketahanan terhadap beban impak yang lebih baik. Frame jenis ini juga mudah untuk dirancang namun cukup sulit dalam hal konstruksinya. Pengaplikasian jenis tubular frame chassis sangat cocok diterapkan pada jenis kendaraan ringan atau mobil balap, contohnya pada mobil balap Formula SAE.

Struktur jenis ini sangat penting untuk memastikan semua beam sepenuhnya terhubung secara triangulasi sehingga sambungan yang terdapat pada chassis lebih kokoh. Oleh karena sambungan las, beberapa hambatan lentur dan torsi akan terjadi pada sambungannya, dengan mengandalkan pembatasan tersebut akan membuat struktur jauh lebih kaku.
Tubular space frame dapat memakai berbagai macam pipa jenis circular. Namun, terkadang dipakai juga bentuk squaretube agar mudah disambung, meskipun begitu bentuk circular memiliki kekuatan yang lebih besar. Posisinya yang berbagai arah menghasilkan kekuatan mekanikal untuk melawan gaya dari berbagai arah. Pipa tersebut dilas sehingga terbentuk struktur yang kompleks.

\subsubsection{Monocoque}

Monocoque merupakan satu kesatuan stuktur chassis dari bentuk kendaraannya sehingga chassis ini memiliki bentuk yang beragam yang menyesuaikan dengan body mobil. Meskipun terlihat seperti satu kesatuan dari rangka dan body mobilnya, namun sebenarnya chassis jenis ini dibuat dengan menggunakan pengelasan melalui proses otomasi sehingga hasil pengelasan yang berbentuk sempurna dan terlihat seperti tidak ada hasil pengelasan.

Material yang digunakan adalah baja atau yang lebih ringan seperti carbon fibre sedangkan pada chassis lain digunakan campuran material antara baja dengan aluminium sehingga bobotnya lebih ringan. Kelemahan dari jenis chassis ini adalah tidak memungkinkan untuk pembuatan mobil berskala kecil karena membutuhkan proses produksi menggunakan robot. Monocoque 
chassis biasanya digunakan pada mobilmobil modern, supercar maupun mobil balap, seperti chassis mobil Formula 1 Ferrari SF15-T pada gambar 2.2 di bawah ini

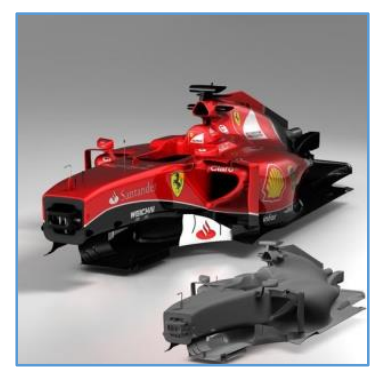

Gambar 2.4 Monocoque Sumber: www.f1technical.net.

\subsubsection{Backbone Chassis}

Backbone chassis adalah jenis chassis dengan struktur depan dan belakangnya yang terhubung dengan sebuah rangka tube yang melintang di sepanjang mobil. Backbone chassis ini hampir seluruhnya adalah struktur kaku dan dapat menahan semua beban. Chassis jenis ini erdapat beberapa lubang yang kontinu. Karena begitu sempit dindingnya umumnya dibuat tebal. Backbone chassis memiliki kekakuan dari luas area bagian "backbone" itu sendiri. Ukuran luas penampangnya sekitar 200 mm x $150 \mathrm{~mm}$. Beberapa jenis chassis mengintegrasikan jenis backbone ini ke struktur utama seperti mobil Low cost. Bentuk rancang bangun chassis jenis tipe ini adalah tetap dengan mengandalkan backbone tetapi dengan menambahkan srtuktur tambahan untuk lebih menambah kekakuan backbone itu sendiri.
Keunggulan chassis backbone adalah bisa di buat dalam berbagai bentuk konstruksi seperti space frame triangular, chassis monocoque angular ataupun tube kontinu. Semua jenis chassis ini digunakan dalam memproduksi sebuah mobil. Hampir semua mobil penggerak belakang dan penggerak depan mengizinkan backbone chassis ini untuk cover transmisi dan ruang poros penggerak.

Namun chassis jenis backbone ini terdapat beberapa kelemahan, yaitu lebih berat untuk menghasilkan kekakuan torsional serta tidak adanya perlindungan jika terjadi tabrakan dari samping (side impact).

\subsubsection{Aluminum Chassis Frame}

Chassis jenis ini pertama kali dikembangkan oleh perusahaan mobil Audi bersama - sama dengan perusahaan pembuat aluminium Alcoa. Aluminium chassis frame dibuat untuk menggantikan chassis baja monocoque karena untuk menghasilkan sebuah rangka yang ringan. Aluminium Space Frame diklaim 40 persen lebih ringan dibanding dengan rangka baja monocoque namun 40 persen lebih rigid.

Berdasarkan jenis-jenis chassis mobil yang telah dijelaskan, jenis tubular space frame chassis menjadi pilihan terbaik karena jenis tersebut cukup kuat dalam menahan 
gaya dari segala arah berkat strukutur yang kompleks. Selain itu, jenis ini lebih tahan terhadap gaya torsional dan paling sering digunakan pada mobil balap Formula SAE. Selain itu, jenis tubular space frame termasuk dalam general requirement dalam regulasi kejuaran Formula SAE. Adapun desain chassis jenis tubular space frame ini mendukung variasi geometri main roll hoop yang merupakan pokok permasalahan dalam tugas akhir ini.

\subsection{Perancangan Chassis Mobil Formula SAE}

Hal paling utama yang perlu diperhatikan sebelum memulai perancangan chassis mobil Formula SAE adalah harus mengetahui dan mengikuti sejumlah peraturan yang berkaitan dengan perencanaan chassis yang mana telah ditetapkan oleh Society of Automotive Engineering International selaku pemegang regulasi kejuaraan Formula SAE. Adapun hal-hal tersebut meliputi konfigurasi chassis itu sendiri serta pemilihan material chassis.

\subsubsection{Konfigurasi Chassis}

Chassis Formula SAE memiliki konfigurasi tersendiri dengan adanya beberapa komponen penting berikut yaitu roll hoop; bracing support; side impact structure; dan front bulkhead. Komponenkomponen tersebut sebagai requirement dalam perancangan chassis. Selain itu, juga berfungsi sebagai perlindungan terhadap pebalap jika sewaktu-waktu mobil mengalami tabrakan (impact force). Gambar 2.2 di bawah ini adalah gambaran sederhana yang mempresentasikan komponenkomponen utama pada chassis Formula SAE.

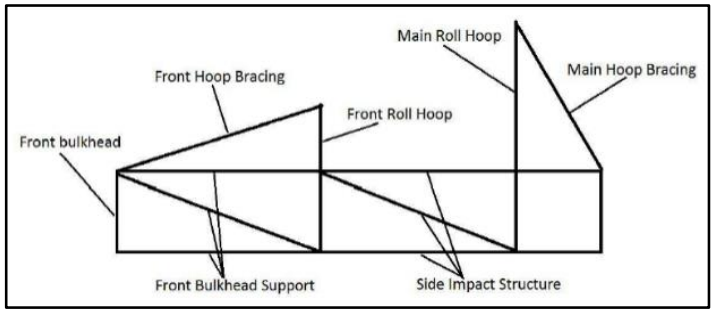

Gambar 2.2 Komponen Utama Chassis Formula $S A E$

(Sumber: Design and Construction of a Space Frame Chassis, 2011)

Roll hoop pada chassis Formula SAE berperan sebagai proteksi terhadap pebalap jika terjadi kecelakaan seperti mobil terbalik atau terguling (rollover). Chassis mobil Formula SAE memiliki dua jenis roll hoop, yaitu main roll hoop yang terletak di atas kepala pebalap dan front roll hoop terletak di depan setir kemudi mobil. Dalam perancangannya, ada aturan-aturan tertentu yang berkaitan dengan kedua jenis roll hoops tersebut.

Regulasi Formula SAE telah menetapkan 95th percentile male template dimension sebagai data antrompometri untuk dimensi pengemudi. 95th dapat diartikan bahwa 95 persen populasi (dalam hal ini adalah 
pengemudi) akan berada pada atau dibawah ukuran yang telah ditetapkan. Gambar $2.8 \mathrm{di}$ bawah menunjukkan dimensi pembalap menggunakan 95th percentile male template dimension sesuai regulasi Formula SAE.

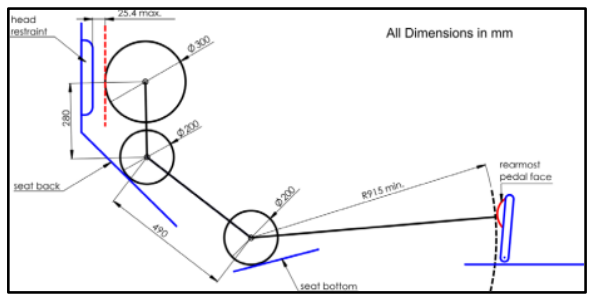

Gambar 2.3 95th Percentile Male Template

Dimension

Source: 2015 Formula SAE Rules

Berdasarkan gambar di atas, dimensi kepala pebalap sudah termasuk helm yaitu 300 milimeter. Kemudian dari data antropometri di atas menjadi acuan dalam menentukan clearance atau jarak antara kepala pebalap dengan geometri atau ketinggian roll hoop, seperti yang dijelaskan pada gambar 2.9 di bawah ini.

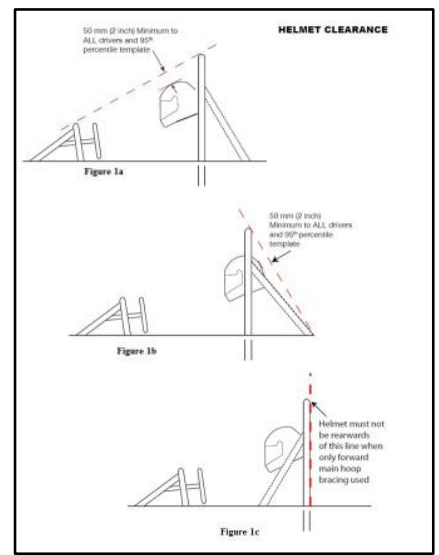

Gambar 2.9 Clearance antara Helm Pebalap dengan Main Roll Hoop

Sumber: 2015 Formlua SAE Rules
Pada chassis Formula SAE untuk memperkuat roll hoop diperlukan komponen lainnya yaitu roll hoop bracing. Pada front roll hoop, posisi bracing harus berada di depan, sedangkan untuk main roll hoop posisi bracing bisa diletakkan di depan atau belakang dari main roll hoop. Berikut penjelasan posisi roll hoop bracing terdapat pada gambar 2.3 di bawah ini.

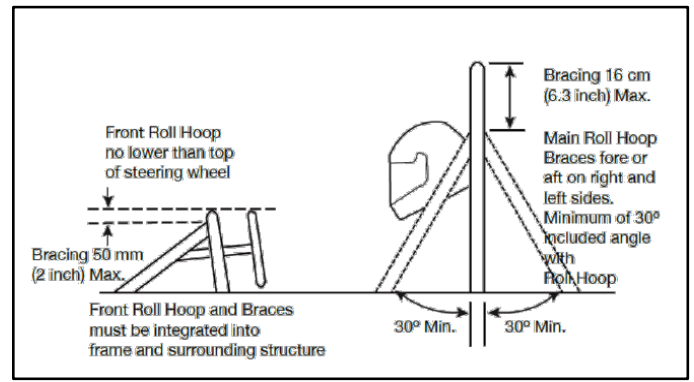

Gambar 2.4 Roll hope blacing

Sumber: 2015 Formula SAE

Berdasarkan gambar di atas, jarak antara maksimum antara puncak bracing dengan main roll hoop adalah 160 milimeter $(6,3$ inci). Untuk sudut kemiringan bracing baik diletakkan di depan maupun di belakang main roll hoop, tidak kurang dari 30 derajat.

\subsubsection{Pemilihan Material}

Material atau bahan adalah benda yang dari mana sesuatu dapat dibuat darinya, atau barang yang dibutuhkan untuk membuat sesuatu, dalam hal ini adalah chassis. Material menjadi sangat penting dalam perancangan chassis mobil Formula 
SAE. Pemilihan material yang tepat akan menghasilkan performa chassis yang bagus.

Hal ini dipengaruhi oleh sifat mekanik dari chassis yang memiliki kemampuan menerima beban, gaya dan energi tanpa menimbulkan kerusakan pada material chassis tersebut. Adapun jika terjadi kerusakan, maka kerusakan tidak boleh melebihi batas toleransi yang telah diizinkan. Tabel di bawah ini adalah ukuran material yang sesuai dengan standar regulasi SAE.

Rules

Table 2.1 Standar Ukuran Material Chassis

Mobil Formula SAE

\begin{tabular}{|l|l|}
\hline ITEM or APPLICATION & \multicolumn{1}{|c|}{$\begin{array}{c}\text { OUTSDE DIMENSION } \\
\text { X WALL THCKNESS }\end{array}$} \\
\hline $\begin{array}{l}\text { Main \& Front Hoops, } \\
\text { Shoulder Harmess Mounting Bar }\end{array}$ & $\begin{array}{l}\text { Round } 1.0 \mathrm{inch}(25.4 \mathrm{~mm}) \times 0.095 \mathrm{inch}(2.4 \mathrm{~mm}) \\
\text { or Round } 25.0 \mathrm{~mm} \times 2.50 \mathrm{~mm} \text { metric }\end{array}$ \\
\hline $\begin{array}{l}\text { Side Impact Structure, Front Bulkhead, } \\
\text { Roll Hoop Bracing, } \\
\text { Driver's Restraint Hamess Attachment } \\
\text { (except as noted above) }\end{array}$ & $\begin{array}{l}\text { Round } 1.0 \mathrm{inch}(25.4 \mathrm{~mm}) \times 0.065 \text { inch }(1.65 \mathrm{~mm}) \\
\text { or Round } 25.0 \mathrm{~mm} \times 1.75 \mathrm{~mm} \text { metric } \\
\text { or Round } 25.4 \mathrm{~mm} \times 1.60 \mathrm{~mm} \text { metric } \\
\text { or Square } 1.00 \mathrm{inch} \times 1.00 \mathrm{inch} \times 0.047 \text { inch }\end{array}$ \\
\hline $\begin{array}{l}\text { EV: Accumulator Protection Structure } \\
\text { or Square } 25.0 \mathrm{~mm} \times 25.0 \mathrm{~mm} \times 1.20 \mathrm{~mm} \text { metric }\end{array}$ \\
\hline $\begin{array}{l}\text { Front Bullkhead Support, Main Hoop } \\
\text { Bracing Supports }\end{array}$ & $\begin{array}{l}\text { Round } 1.0 \mathrm{inch}(25.4 \mathrm{~mm}) \times 0.047 \text { inch }(1.20 \mathrm{~mm}) \\
\text { or Round } 25.0 \mathrm{~mm} \times 1.5 \mathrm{~mm} \text { metric } \\
\text { or Round } 26.0 \mathrm{~mm} \times 1.2 \mathrm{~mm} \text { metric }\end{array}$ \\
\hline
\end{tabular}

Sumber: 2015 Formula SAE

Berdasarkan regulasi, jenis material untuk chassis Formula SAE adalah baja, baik baja ringan (mild steel) atau baja paduan (alloy steel) dengan kandungan karbon minimal 0,1 persen. Material yang digunakan minimal memiliki nilai sebagai berikut:

$$
\begin{array}{ll}
\text { Young's Modulus (E) } & =200 \mathrm{Gpa} \\
\text { Yield Strentgh (Sy) } & =305 \mathrm{Mpa} \\
\text { Ultimate Strentgh (Su) } & =365 \mathrm{Mpa}
\end{array}
$$

Pemilihan suatu bahan teknik mempunyai beberapa aspek yang benarbenar memerlukan peninjauan yang cukup teliti. Peninjauan tersebut antara lain:

1) Pertimbangan sifat, meliputi:
a. Kekuatan
b. Kekerasan
c. Elastisitas
d. Keuletan
e. Daya tahan terhadap korosi
f. Daya tahan fatik
g. Daya tahan mulur

2) Pertimbangan fabrikasi, meliputi:
a. Mampu mesin
b. Kemudahan sambungan las

Berdasarkan pertimbangan di atas, material atau bahan yang digunakan untuk chassis Formula SAE adalah baja ringan (mild steel) AISI 4620 karena memiliki nilai kekuatan lebih tinggi dari standar regulasi. Material baja ringan AISI 4620 memiliki nilai kekuatan sebagai berikut:

$$
\begin{array}{ll}
\text { Young's Modulus (E) } & =205 \mathrm{Gpa} \\
\text { Yield Strentgh (Sy) } & =317 \mathrm{Mpa} \\
\text { Ultimate Strentgh (Su) } & =429 \mathrm{Mpa}
\end{array}
$$

Dimensi material yang digunakan pada chassis ini adalah round tube $26,9 \mathrm{~mm} \times 2,5$ $\mathrm{mm}$ untuk komponen front dan main roll hoop, sedangkan komponen lainnya seperti roll hoop bracing, frront bulkhead, side 
impact structure dan bagian main frame menggunakan round tube $26,9 \mathrm{~mm} \times 2 \mathrm{~mm}$.

\subsection{Deflection}

Defleksi adalah perubahan bentuk pada balok dalam arah tertentu akibat adanya pembebanan vertikal yang diberikan pada balok atau batang. Deformasi pada balok secara sangat mudah dapat dijelaskan berdasarkan defleksi balok dari posisinya sebelum mengalami pembebanan. Defleksi diukur dari permukaan netral awal ke posisi netral setelah terjadi deformasi. Konfigurasi yang diasumsikan dengan deformasi permukaan netral dikenal sebagai kurva elastis dari balok. Gambar 1 (a) memperlihatkan balok pada posisi awal sebelum terjadi defleksi dan gambar 1 (b) adalah balok setelah terjadi defleksi dan dalam konfigurasi terdeformasi yang diasumsikan akibat aksi pembebanan.

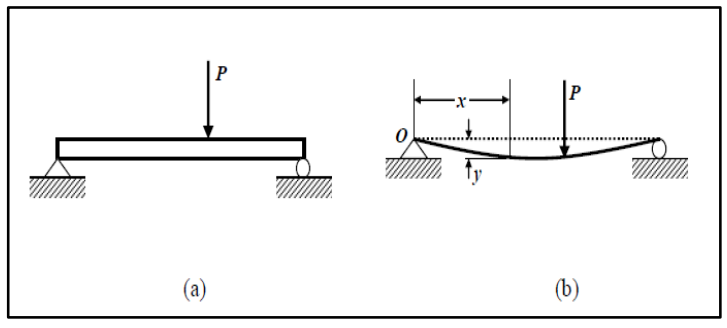

Gambar 2.5 (a) Balok sebelum terjadi defleksi, (b) Balok setelah terjadi defleksi Sumber:http://bambangpurwantana.staff. ugm.ac.id/KekuatanBahan

Jarak perpindahan (displacement) y didefinisikan sebagai defleksi balok. Dalam penerapan, kadang kita harus menentukan defleksi pada setiap nilai $\mathrm{x}$ disepanjang balok. Hubungan ini dapat ditulis dalam bentuk persamaan yang sering disebut persamaan defleksi kurva (atau kurva elastis) dari balok.

\subsubsection{Hal yang Mempengaruhi Terjadinya Deflkesi}

Defleksi terjadi disebabkan oleh beberapa hal yaitu kekakuan batang, gaya yang diberikan, jenis tumpuan, jenis beban yang diberikan.

1) Kekakuan batang

Semakin kaku suatu batang maka lendutan batang yang akan terjadi pada batang akan semakin kecil.

2) Besarnya kecil gaya yang diberikan Besar-kecilnya gaya yang diberikan pada batang berbanding lurus dengan besarnya defleksi yang terjadi. Dengan kata lain semakin besar beban yang dialami batang maka defleksi yang terjadi pun semakin kecil.

3) Jenis tumpuan yang diberikan

Jumlah reaksi dan arah pada tiap jenis tumpuan berbeda-beda. Jika karena itu besarnya defleksi pada penggunaan tumpuan yang berbeda-beda tidaklah sama. Semakin banyak reaksi dari tumpuan yang melawan gaya dari beban maka defleksi yang terjadi pada tumpuan rol lebih besar dari tumpuan pin (pasak) dan defleksi yang terjadi pada tumpuan pin lebih besar dari tumpuan jepit. 
4) Jenis beban yang terjadi pada batang

Beban terdistribusi merata dengan beban titik,keduanya memiliki kurva defleksi yang berbeda-beda. Pada beban terdistribusi merata slope yang terjadi pada bagian batang yang paling dekat lebih besar dari slope titik. Ini karena sepanjang batang mengalami beban sedangkan pada beban titik hanya terjadi pada beban titik tertentu saja.

\subsubsection{Aplikasi Lendutan Batang}

Aplikasi dari analisa lendutan batang dalam bidang keteknikan sangat luas, mulai dari perancangan poros transmisi sebuah kendaraan bermotor maupun perancangan chassis. Hal ini menujukkan bahwa pentingnya analisis lendutan batang dalam perancangan sebuah konstruksi teknik. Berikut adalah beberapa aplikasi dari lendutan batang:
1) Jembatan
Di sinilah dimana aplikasi lendutan batang mempunyai perananan yang sangat penting. Sebuah jembatan yang fungsinya menyeberangkan benda atau kendaraan diatasnya mengalami beban yang sangat besar dan dinamis yang bergerak diatasnya. Hal ini tentunya akan mengakibatkan terjadinya lendutan batang atau defleksi pada batang-

batang konstruksi jembatan tersebut. Defleksi yang terjadi secara berlebihan tentunya akan mengakibatkan perpatahan pada jembatan tersebut dan hal yang tidak diinginkan dalam membuat jembatan

\section{2) Poros Transmisi}

Pada poros transmisi roda gigi yang saling bersinggungan untuk mentransmisikan gaya torsi memberikan beban pada batang poros secara radial. Ini yang menyebabkan terjadinya defleksi pada batang poros transmisi. Defleksi yang terjadi pada poros membuat sumbu poros tidak lurus. Ketidaklurusan sumbu poros akan menimbulkan efek getaran pada pentransmisian gaya torsi antara roda gigi.

3) Rangka (chasis) kendaraan

\section{Kendaraan-kendaraan}

pengangkut yang berdaya muatan besar, memiliki kemungkinan terjadi defleksi atau lendutan batangbatang penyusun konstruksinya.

4)Konstruksi Badan Pesawat Terbang Pada perancangan sebuah pesawat material-material pembangunan pesawat tersebut merupakan material-material ringan 
dengan tingkat elestitas yang tinggi namun memiliki kekuatan yang baik. Oleh karena itu, diperlukan suatu analisis lendutan.

\section{Metode Penelitian}

Tahapan penelitian yang diakukan merupakan langkah awal dalam perancangan dan membangun sebuah alat, dalam hal ini adalah chassis mobil Formula SAE. Adapun tahapan penelitian dijabarkan melalui flow chart berikut.

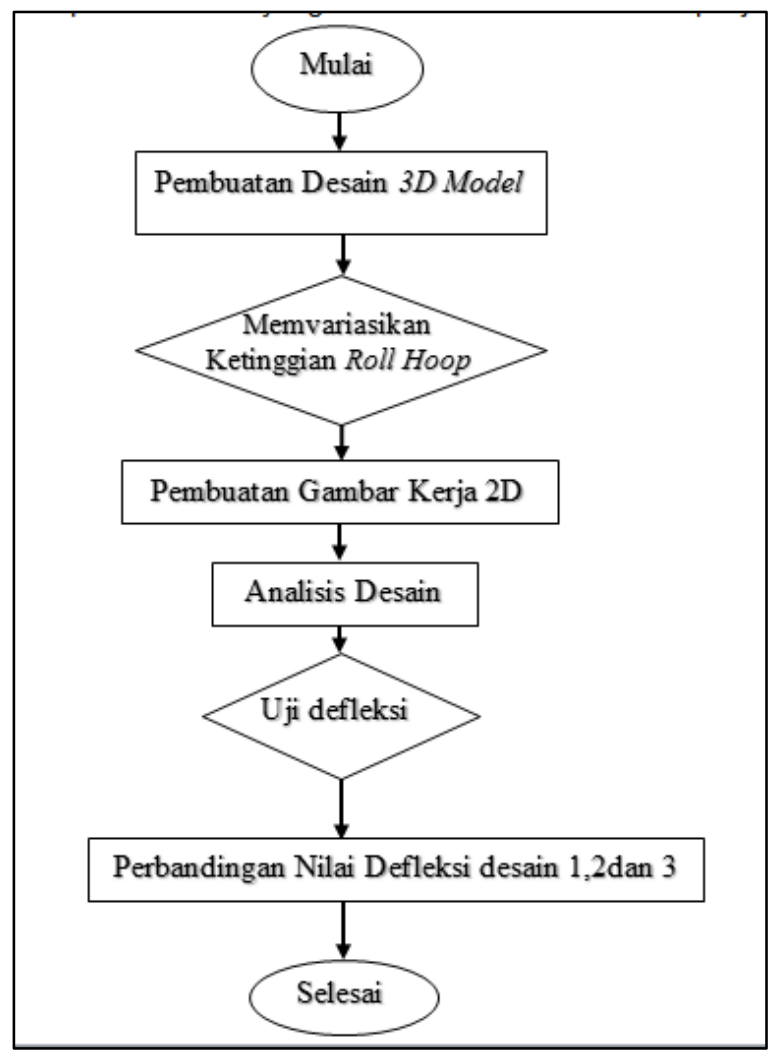

Gambar 3.1 Flow Chart Tahapan

PenelitianSources:

1) Pembuatan Desain 3D Model

Langkah awal dari penelitian ini adalah membuat permodelan tiga dimensi dari chassis Formula SAE. Proses desain dilakukan dengan menggunakan sofware Autodesk Inventor . Untuk variasi desainnya sendiri yaitu difokuskan pada variasi geometri main roll hoop..

2) Pembuatan Gambar Kerja 2D

Gambar kerja dua dimensi dibuat menggunakan perangkat lunak yang sama yaitu Autodesk Inventor. Tujuan dari pembuatan gambar 2D ini adalah untuk memberikan penjelasan lebih detail terhadap desain chassis.

3) Analisis Desain

Analisis desain dilakukan bertujuan untuk mengetahui besar defleksi yang terjadi pada desain chassis. Analisis berupa simulasi gaya pada komponen utama chassis seperti front dan main roll hoop, side impact structure, front bulkhead dan front bulkhead support adalah sebagai uji struktural chassis. Nila dan arah gaya yang diaplikasikan menyesuaikan dengan structural requirements dari regulasi Formula SAE. Analisis desain menggunakan fitur frame analysis dari Autodesk Invento.

4) Perbandingan Nilai Displacement

Nilai displacement atau biasa dikenal dengan defleksi didapat dari hasil simulasi chassis. Maximum displacement yang diizinkan regulasi pada setiap komponen yang diberi gaya adalah 25 
milimeter. Variasi geometri roll hoop untuk mengetahui perbandingan nilai displacement pada tiap-tiap variasi. Geometri roll hoop terbaik adalah yang memiliki nilai displacement terkecil.

\subsection{Variabel Penelitian}

Ketinggian dari main roll hopp menjadi varabel dalam penelitian ini, dan akan disimulasikan menggunakan software Autodesk Inventor untuk mengetahui besar defleksi dari masing-masing variasi main roll hoop.

\subsection{Kesulitan Selama Penelitian}

Beberapa kesulitan yang muncul dalam melakukan penelitian ini adalah pada fitur frame analysis yang ada di Autodesk Inventor Professional 2016 tidak mendukung simulasi jika pada chassis terdapat geometri berbentuk radius. Hal ini dikarenakan fitur frame analysis akan mengkonvert setiap komponen chassis menjadi konstruksi batang lurus (beam) sehingga mengurangi kebebasan dalam melakukan desain chassis.

Kesulitan lainnya adalah akan terdapat selisih atau error antara hasil simulasi menggunakan software dengan fakta di lapangan jika nantinya dilakukan proses manufaktur untuk membuat chassis ini.

\section{4. Hasil dan Pembahasan}

\subsection{Hasil}

Hasil simulasi desain 1, dimensi roll hope dengan ketinggian $518 \mathrm{~mm}$, menghasilkan defleksi 14,16 mm.

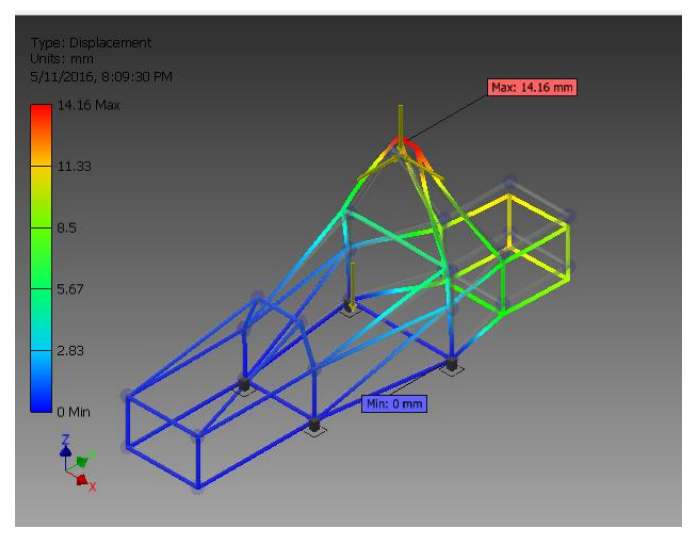

Figure 4.1

Sumber: Auto desk inventor 2016

Hasil Simulasi desain 2, dimensi roll hoop dengan ketinggian $525 \mathrm{~mm}$, menghasilkan defleksi 14,94 mm. Sumber: Auto desk inventor 2016.

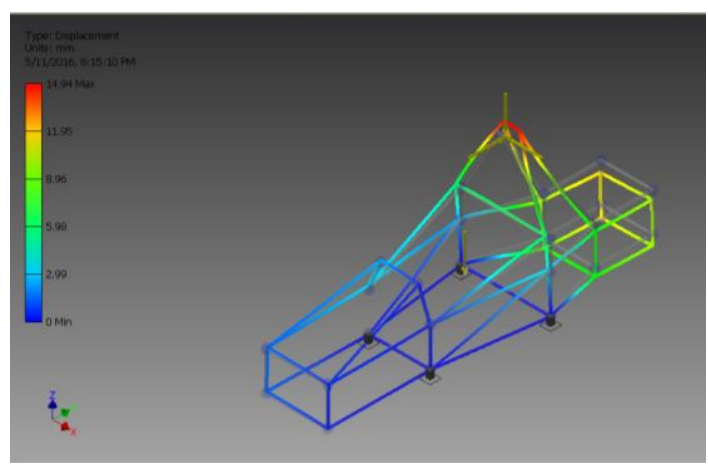

Figure 4.2

Source: Auto desk inventor 2016

Hasil simulasi desain 3 , dimensi roll hoop dengan ketinggian 532 menghasilkan defleksi 20,37. 


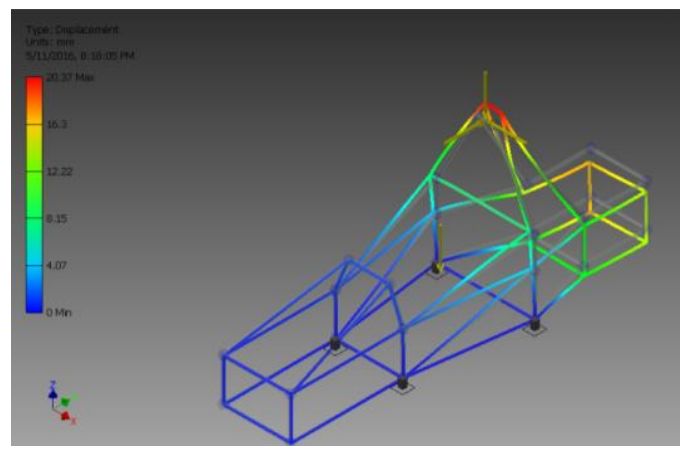

Figure 4.3

Source: Auto desk inventor 2016

Table 2.2 Comparison Normal stress design 1,2, and 3 on chassis

\begin{tabular}{|l|c|c|c|c|c|}
\hline $\begin{array}{c}\text { Tipe } \\
\text { chasis }\end{array}$ & $\begin{array}{c}\text { Tinggi } \\
\text { Roll } \\
\text { Hope }\end{array}$ & $\begin{array}{c}\text { Beban } \\
\text { Fx }\end{array}$ & $\begin{array}{c}\text { Beban } \\
\text { Fy }\end{array}$ & $\begin{array}{c}\text { Beban } \\
\text { Fz }\end{array}$ & $\begin{array}{c}\text { Defleksi } \\
\text { (mm) }\end{array}$ \\
\hline 1 & 518 & $6 \mathrm{kN}$ & $5 \mathrm{kN}$ & $9 \mathrm{kN}$ & 14,16 \\
\hline 2 & 525 & $6 \mathrm{kN}$ & $5 \mathrm{kN}$ & $9 \mathrm{kN}$ & 14,94 \\
\hline 3 & 532 & $6 \mathrm{kN}$ & $5 \mathrm{kN}$ & $9 \mathrm{kN}$ & 20,37 \\
\hline
\end{tabular}

Sources:

Table 2.3 Comparison of shear stress $(\mathrm{x})$ designs 1,2 and 3

\begin{tabular}{|l|l|l|l|l|l|}
\hline $\begin{array}{c}\text { Tipe } \\
\text { chasis }\end{array}$ & $\begin{array}{c}\text { Tinggi } \\
\text { Roll } \\
\text { Hope }\end{array}$ & $\begin{array}{c}\text { Beban } \\
\text { Fx }\end{array}$ & $\begin{array}{c}\text { Beban } \\
\text { Fy }\end{array}$ & $\begin{array}{c}\text { Beban } \\
\text { Fz }\end{array}$ & $\begin{array}{c}\text { Normal } \\
\text { Stress } \\
\text { (MPa) }\end{array}$ \\
\hline 1 & 518 & $6 \mathrm{kN}$ & $5 \mathrm{kN}$ & $9 \mathrm{kN}$ & 598,6 \\
\hline 2 & 525 & $6 \mathrm{kN}$ & $5 \mathrm{kN}$ & $9 \mathrm{kN}$ & 678,7 \\
\hline 3 & 532 & $6 \mathrm{kN}$ & $5 \mathrm{kN}$ & $9 \mathrm{kN}$ & 682,7 \\
\hline
\end{tabular}

Sources:

Table 2.4 Comparison of shear stress $(\mathrm{x})$ designs 1,2 and 3

\begin{tabular}{|l|c|l|l|l|l|}
\hline $\begin{array}{c}\text { Tipe } \\
\text { Chasis }\end{array}$ & $\begin{array}{c}\text { Tinggi } \\
\text { Roll } \\
\text { Hope }\end{array}$ & $\begin{array}{c}\text { Beban } \\
\text { Fx }\end{array}$ & $\begin{array}{c}\text { Beban } \\
\text { Fy }\end{array}$ & $\begin{array}{c}\text { Beban } \\
\text { Fz }\end{array}$ & $\begin{array}{c}\text { Shear } \\
\text { Stress(X) } \\
\text { (Mpa) }\end{array}$ \\
\hline 1 & 518 & $6 \mathrm{kN}$ & $5 \mathrm{kN}$ & $9 \mathrm{kN}$ & 74,76 \\
\hline 2 & 525 & $6 \mathrm{kN}$ & $5 \mathrm{kN}$ & $9 \mathrm{kN}$ & 75,7 \\
\hline 3 & 532 & $6 \mathrm{kN}$ & $5 \mathrm{kN}$ & $9 \mathrm{kN}$ & 72,83 \\
\hline \multicolumn{6}{|c|}{ Sources: }
\end{tabular}

Table 2.5 Comparison of shear stress (Y)

\begin{tabular}{|l|c|c|c|c|c|}
\hline $\begin{array}{c}\text { Tipe } \\
\text { Chasis }\end{array}$ & $\begin{array}{c}\text { Tinggi } \\
\text { Roll } \\
\text { Hope }\end{array}$ & $\begin{array}{c}\text { Beban } \\
\text { Fx }\end{array}$ & $\begin{array}{c}\text { Beban } \\
\text { Fy }\end{array}$ & $\begin{array}{c}\text { Beban } \\
\text { Fz }\end{array}$ & $\begin{array}{c}\text { Shear } \\
\text { Stress(Y) } \\
\text { (Mpa) }\end{array}$ \\
\hline 1 & 518 & $6 \mathrm{kN}$ & $5 \mathrm{kN}$ & $9 \mathrm{kN}$ & 31,93 \\
\hline 2 & 525 & $6 \mathrm{kN}$ & $5 \mathrm{kN}$ & $9 \mathrm{kN}$ & 30,51 \\
\hline 3 & 532 & $6 \mathrm{kN}$ & $5 \mathrm{kN}$ & $9 \mathrm{kN}$ & 24,48 \\
\hline
\end{tabular}

Sources:

Table 2.6 Comparison of Torsional stress chassis design 1, 2 and 3

\begin{tabular}{|l|c|c|c|c|c|}
\hline $\begin{array}{c}\text { Tipe } \\
\text { Chasis }\end{array}$ & $\begin{array}{c}\text { Tinggi } \\
\text { Roll } \\
\text { Hope }\end{array}$ & $\begin{array}{c}\text { Beban } \\
\text { Fx }\end{array}$ & $\begin{array}{c}\text { Beban } \\
\text { Fy }\end{array}$ & $\begin{array}{c}\text { Beban } \\
\text { Fz }\end{array}$ & $\begin{array}{c}\text { Torsional } \\
\text { stress } \\
\text { (Mpa) }\end{array}$ \\
\hline 1 & 518 & $6 \mathrm{kN}$ & $5 \mathrm{kN}$ & $9 \mathrm{kN}$ & 31,93 \\
\hline 2 & 525 & $6 \mathrm{kN}$ & $5 \mathrm{kN}$ & $9 \mathrm{kN}$ & 30,51 \\
\hline 3 & 532 & $6 \mathrm{kN}$ & $5 \mathrm{kN}$ & $9 \mathrm{kN}$ & 24,48 \\
\hline \multicolumn{6}{|c|}{ Sources: } \\
\hline
\end{tabular}

\subsection{Pembahasan}

Gambar di bawah hubungan Tinggi roll hope dengan defleksi, disini dapat diihat kecenderungan semakin tinggi roll hope maka defleksi yang dihasilkan semakin besar.Defleksi maksimum terjadi pada tinggi roll hope $532 \mathrm{~mm}$ yaitu sebesar 20,37 .

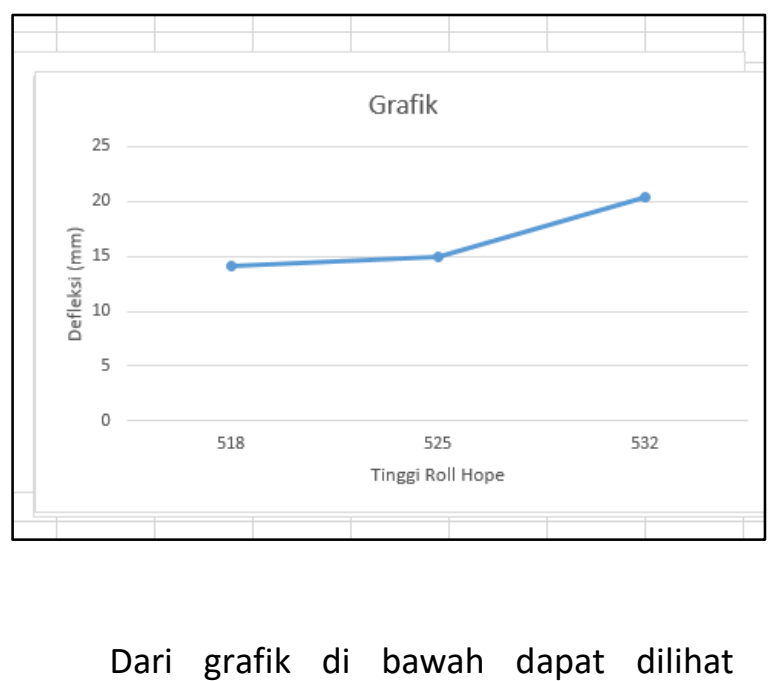

bahwa untuk tinggi rollhope 518 tegangan 
normal (normal stress ) sebesar 598,6 MPa, untuk ketinggian 525 mengalami tegangan normal sebesar $678,7 \mathrm{MPa}$ dan pada ketinggiaan 532 mengalami tegangan normal sebesar 682,7 MPa.

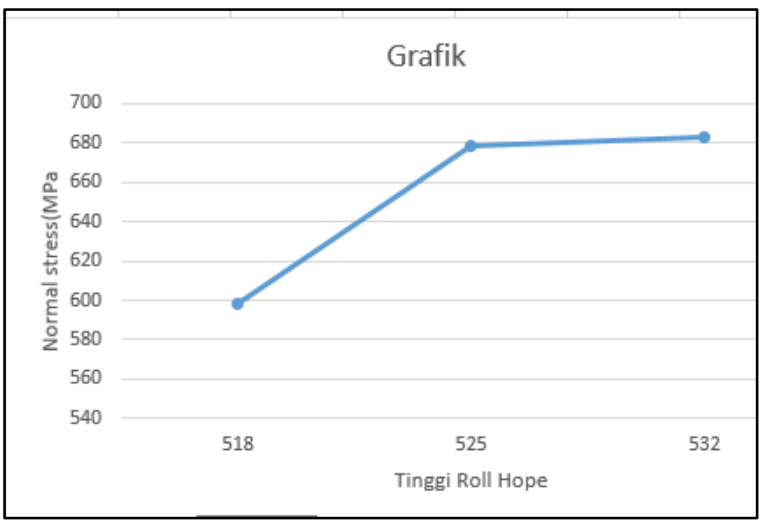

Dari grafik di bawah dapat dilihat hubungan tinggi roll hope, pada saat tinggi roll hope $518 \mathrm{~mm}$ terjadi tegangan geser $(x)$ 74,76 $\mathrm{MPa}$, sedangkan tinggi roll hope 525 mengalami tegangan geser $(x)$ sebesar 75,7 MPa. Untuk ketinggian roll hope 532 mengalami tegangan geser $(x)$ sebesar 72,83 $\mathrm{MPa}$.

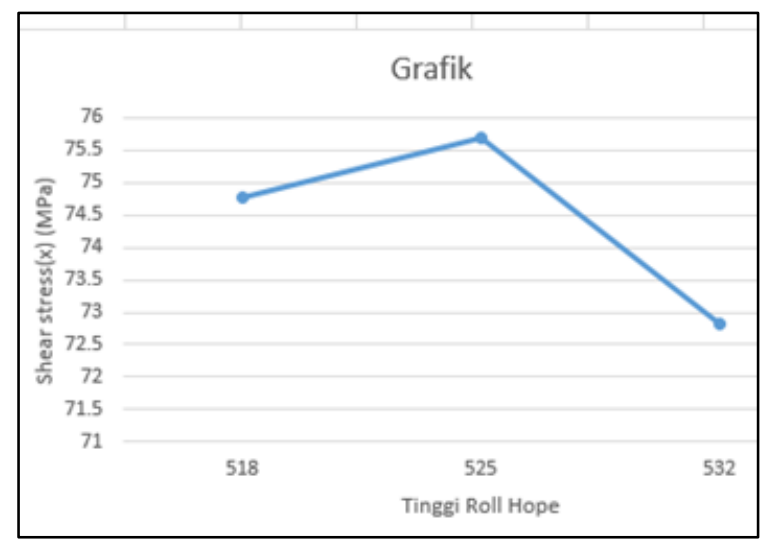

Hubungan grafik tinggi roll hope - tegangan geser (shear stress) (y) dapat dilihat di bawah , pada saat tinggi roll hope $518 \mathrm{~mm}$ terjadi tegangan geser (y) 31,93 $\mathrm{MPa}$, untuk ketinggian roll hope $525 \mathrm{~mm}$ terjadi tegangan geser (y) sebesar 30,51 MPa, sedangkan untuk ukuran roll hope $532 \mathrm{~mm}$ mengalami tegangan geser (y) sebesar 24,48 MPa.

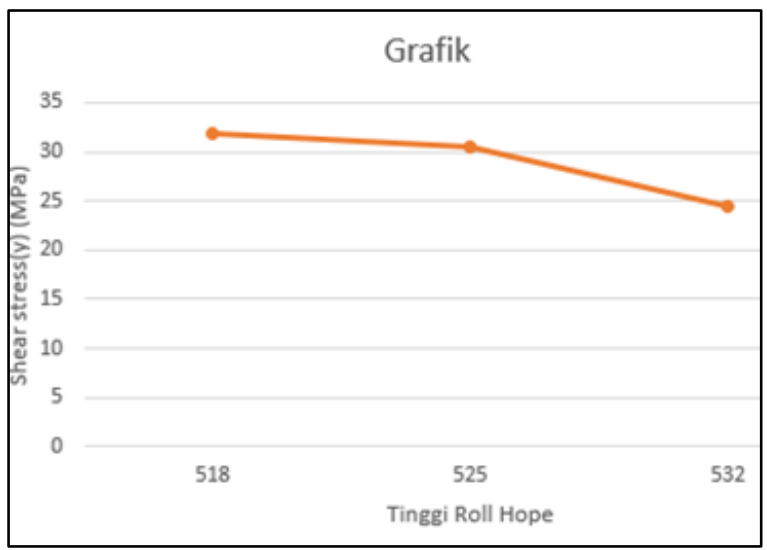

Dari hasil analisis tegangan diperoleh grafik hubungan tinggi roll hope dan tegangan torsi (torsional stress). Pada ukuran tinggi roll hope $518 \mathrm{~mm}$ mengalami tegangan torsi sebesar 31,93 $\mathrm{MPa}$, selanjutnya tinggi roll hope $525 \mathrm{~mm}$ mengalami tegangan torsi sebesar 30,51 $\mathrm{MPa}$, dan pada tinggi roll hope $532 \mathrm{~mm}$ mengalami tegangan sebesar 24,48 MPa.

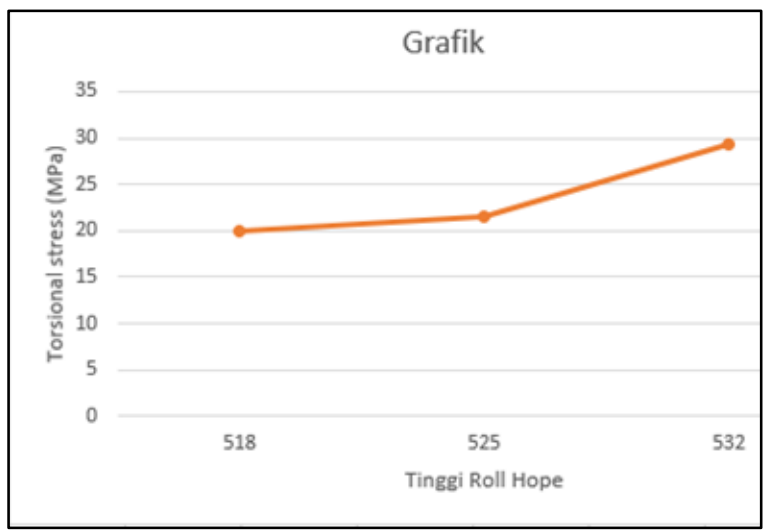




\section{PENUTUP}

\begin{abstract}
Kesimpulan
Dari hasil perhitungan tegangan menggunakan simulasi software inventor didapat nilai tegangan terendah desain sasis dengan ketinggian roll hope $518 \mathrm{~mm}$ dengan nilai defleksi 14,16 mm, tegangan normal 598,6 MPa. Sedangkan tegangan torsi dan tegangan geser nilai terendah didapat pada ketinggian roll hope 531. Pertimbangan dalam menentukan tinggi roll hope semakin pendek roll hope maka defleksinya semakin mininmum (stabil) dan juga semakin pendek roll hope
\end{abstract}

\section{Daftar Pustaka}

Afandy Munandar, Faris. 2011. Analisis eksperimental Dan Teoritis Lendutan Pada Balok Dengan Variasi Ketebalan Dan Pembebanan. Jurnal Penelitian. Makassar: Fakultas Teknik, Universitas Hasanuddin. Finite Element Analysis of Formula Student Chasis Middlesbrough: School of Science \& Engineering, Teeside University England Baker, Christopher Scott 2004. FoES Formula SAE-A Space Frame Chassis Design. Queensland Faculty of engineering \& surveying. University Of shouter queensland Australia.

Bawa, H.S. 2004. Manufacturing Process II. Tata McGraw-Hill New Delhi menghasilkan tegangan normal minimum (life time) suatu bahan lebih tahan lama.

\section{Saran}

Sebaiknya dikembangkan analisisis defleksi pada chasis mobil formula SAE menggunakan metode eksperimental dengan bantuan alat ukur sehingga didapat nilai yang lebih akurat.

Perlu diteliti defleksi dibagian lainnya seperti bagian front hope atau bagian side impact sehingga akan mendapat data yang lebih lengkap tentang kekuatan desain chasis mobil formula

SAE.

Daryanto 2010. Proses Pengolahan Besi dan Baja

(ilmu Metalurgi). Bandung: Satu Nusa.

Fadila, Ary dan Bustami Syam. 2013. Analisis

Simulasi Struktur Chasis Mobil Mesin USU Berbahan Besi Strukur terhadap beban Statik dengan menggunakan Perangkat Lunak ANSYS 14.5. Jurnal Penelitian Medan : Fakultas Teknik, Universitas Sumatra Utara.

Fadlil Adhim, Muhammad dan Alief Wikarta. 2013. Analisis Struktural Performa chasis Sapuangin Speed 2013. Jurnal Penelitian Surabaya: Fakultas Teknologi Industri, Institut Teknologi Sepuluh Nopember 
Kosasih, Prabuono Buyung. 2012. Teori dan Aplikasi metode Elemen Hingga. Yogyakarta: Penerbit ANDI.

Meredith D., Dale et al. 1992. Perancangan

Perencanaan system rekayasa. Jilid 1. Edisi kedua. Diterjemahkan oleh Agus Maulana. Jakarta : Penerbit Erlangga.

Meriam, J.L dan L.G. Kraige. 2004. Engineering Mechanic Static, ed. 5. John Wiley \& Sons (Asia)

Pte.Ltd.:Singapore.

Mitchell, Larry D. dan Joseph Edward Shigley.1991. Perancanaan Teknik Mesin, ed 4. Diterjemahkan oleh: Gandhi Harahap.Jakarta: Erlangga.

Munandar, F. dan Arfandy. 2011. Analisis Eksperimental Dan Teoritis Lendutan Pada Balok Dengan Variasi Ketebalan Dan Pembebanan. Skripsi. Makasar: Universitas Hasanudin

Pinem, Mhd. Daud. 2010. Mekanika Kekuatan Material Lanjut Bandung: Rekayasa Sains

Sutantra, I Nyoman. 2001. Teknologi Otomotif Teori dan Aplikasinya Surabaya: Prima Printing. Cannon, J.L and L.G. Kraige. 2004. Engineering Mechanic Static, ed. 5. John Wiley \& Sons (Asia) Pte.Ltd.:Singapore.

Mitchell, Larry D. and Joseph Edward Shigley.1991. Planning of Mechanical Engineering, ed 4. Translated by: Gandhi Harahap.Jakarta: Erland.
Munandar, F. and Arfandy. 2011. Experimental And Theoretical Analysis Deflection On Beam With Variation Of Thickness And Charging. Essay. Makasar: Hasanuddin University Pinem, Mhd. David. 2010. Advanced Material Strength Mechanics Bandung: Engineering Science

Sutantra, I Nyoman. 2001. Automotive Technology Theory and Its Application Surabaya: Prima Printing 